\title{
IMPACT OF THE NEW PACT ON MIGRATION AND ASYLUM ON CHILD REFUGEES AND UNACCOMPANIED MINORS
}

\author{
Dunja DUIĆ \\ Assistant Professor, Josip Juraj Strossmayer University of Osijek \\ Faculty of Law \\ E-mail: dduic@pravos.hr \\ Marina ČEPO \\ Teaching and Research Assistant, Josip Juraj Strossmayer University of \\ Osijek, Academy of Arts and culture \\ E-mail: mcepo@uaos.hr
}

\begin{abstract}
In the wake of the refugee and migration crisis in 2015, the European Union changed its legislation with a view to improving the protection of refugees, as well as children and unaccompanied minors. As part of the changes, the European Commission proposed the New Pact on Migration and Asylum, which drastically amends the Common European Asylum Policy. The Commission also withdrew the Proposal to amend the Dublin III Regulation on grounds of being contrary to the case law of the Court of Justice of the European Union concerning the transfer of a child to the country of first entry. The New Pact on Migration and Asylum envisages procedures to take place at the external borders of the EU and exempts unaccompanied children and children under the age of twelve together with their families from border procedures. Such setting of the age limit of a child outright contradicts the definition of a child under the Convention on the Rights of the Child and the case law of the Court of Justice of the European Union, which determine it as any person under the age of eighteen is considered a child. A burning issue is the current practice of treating asylum-seeking children and minors principally as asylum seekers and not children. While they may be asylum seekers, they are children and minors first, and as such must be protected primarily by international law
\end{abstract}


relating to their protection. Although the 1951 Convention relating to the Status of Refugees also applies to children, nowhere is the term refugee child explicitly defined. Comparably, while the Convention on the Rights of the Child does recognize the term refugee child, it provides limited guidance to States Parties to identifying and assessing the refugee status of the child. In arguing that the New Pact on Migration and Asylum should be in line with international refugee law and the Convention on the Rights of the Child and abide by the principle of the best interest of the child, this paper will attempt to answer the following: Is the New Pact on Asylum and Migration in compliance with the principle of the best interests of the child? Does it protect the asylumseeking child as required by international and European law?

Key words: migration, child, refugees, asylum, pact

\section{INTRODUCTION}

As asylum seekers, children and minors are a particular and vulnerable group. In the international law framework, their diposition is dual: while the 1951 Convention Relating to the Status of Refugees (CSR) sets the standards concerning their refugee and asylum seeker status, the 1989 Convention on the Rights of the Child (CRC) protects their fundamental rights as children, taking into account the age-related specificities and vulnerabilities. ${ }^{1}$ However, in practice, when seeking asylum, children and minors are treated principally as asylum seekers, and not children. The first part of this paper presents an overview of the rights of the child, as provided under the CRC, and its best interests. The second part examines the specificities of refugee law concerning asylum-seeking child refugees and unaccompanied minors. Next, it analyzes the New Pact on Migration and Asylum (PMA) that brought amendments in relation to minors under the asylum procedure, which amendments are partly contrary to the position of the Court of Justice of the European Union (CJEU) and the institution of the best interest of the child. Safeguarding a child's best interest should be the goal of any decision relating to asylum-seeking child refugees and unaccompanied minors. With the New PMA, the European Commission's (EC) intent was to improve the protection of child refugees and unaccompanied minors, with a special emphasis on the institution of the best

\footnotetext{
${ }^{1}$ Translation of all government and legislative material is from the official translation websites as referenced in the bibliography.
} 
Impact of the new pact on migration and asylum on child refugees ...

interests of the child. Has the EC succeeded? Is the New PMA in line with the international law standards? Following an exploration into these questions, this paper will suggest certain guidelines de lege ferenda that could translate to an improvement of the European Union's (EU) asylum system and the protection of child refugees and unaccompanied minors within the EU.

\section{TWOFOLD PROTECTION OF CHILD REFUGEES UNACCOMPANIED MINORS IN INTERNATIONAL LAW}

AND

The vital document to have affected the improvement of child rights is certainly the CRC. It is precisely the CRC that represents a catalogue of child rights.

In defining the child as "every human being below the age of eighteen years unless under the law applicable to the child, majority is attained earlier" (Article 1), the CRC allows for a relatively broad age range, while considering the varied national regulations and differing definitions of age of majority. Per Hrabar (2013), the CRC sets four basic priniciples: non-discrimination, best interest of the child, the right of child to life, subsistence and development, and right of child to express opinion and participate in decision-making in matters affecting him or her in accordance with his or her age and maturity. Even though, as Freeman (2007) sees it, no one principle overrides another, the best interest of the child may be viewed as the foundation of the other principles. The rights of the child as provided for by the CRC transcend the rights under the European Convention on Human Rights (ECHR): per Article 8 to the CRC, States Parties are to respect the right of the child to preserve his or her identity, including nationality, name and family relations as recognized by law without unlawful interference. Another vital and irreplaceable element in the protection of children's rights is the European Court of Human Rights (ECtHR) (Van Bueren, 2007). The right of the child to have its best interests taken into account is the fundamental rule, interpretive legal obligation and procedural rule (UN Committee on the Rights of the Child, 2016; Kilkelly, 2016). The principle of the best interest of the child did exist before the adoption of the CRC: Principle 2 of the 1959 Declaration of the Rights of the Child prescribed that the best interests of the child be the paramount consideration (UN General Assembly, 1959). It is this very principle that the CRC underlined as central in guiding decisions on the rights and welfare of the child.

At its outset, the institution of the best interest of the child had limited scope and was taken into account in divorce proceedings and child custody decisions (Alston, 1994). Owing to the CRC, today this institution encompasses all childrelated circumstances. While it has been incorporated into a vast majority of 
legislation, the best interest of the child as an institution suffers under differing interpretations and, in turn, applications, depending on a given country (Degol and Dinku, 2011).

At any rate, all legislative, administrative and judicial bodies and/or institutions are required to apply the best interest principle by systematically considering how children's welfare will be affected by their decisions, and to adjust their actions in accordance with children's needs (UN Committee on the Rights of the Child, 2003).

The CRC touches on the rights of child refugees expressly, including unaccompanied minors as well as asylum seekers from that bracket whose refugee status has yet to be granted. Per Article 22(1) to the CRC, States Parties are to take appropriate measures to ensure that a child who is seeking refugee status or who is considered a refugee in accordance with applicable international or domestic law and procedures shall, whether unaccompanied or accompanied by his or her parents or by any other person, receive appropriate protection and humanitarian assistance in the enjoyment of applicable rights set forth in the present Convention and in other international human rights or humanitarian instruments to which the said States are Parties. The Article further prescribes that in cases where no parents or other members of the family can be found, the child is to be accorded the same protection as any other child permanently or temporarily deprived of his or her family environment for any reason. This provision of Article 22 to the CRC in fact refers to its Article 20 that pertains to children who have been temporarily or permanently deprived of their family environment, or for whose own welfare cannot be allowed to remain in that environment, in which case they are entitled to special protection and assistance provided by the state. Per Article 20 (2), States Parties must ensure alternative care for such a child in accordance with their national laws. Such direct reference to national legislation of CRC States Parties is pivotal: the legislation that is closest to a child, and as such immediately applicable in the country the child finds itself, is certainly in the best interest of the child.

Article 22 of the CRC remains the only provision of international law that is concerned with human rights protection, and, specifically, the disposition of child refugees, unaccompanied minors and children seeking refugee status (Pobjoy, 2017). While there have been attempts, the introduction of the definition of child refugee into the CRC would have implied, as Van Bauren (2020) finds, amending the CSR and the 1967 Protocol - an action that lacked commitment from the States Parties. Defining child refugee and asylum-seeking child would contribute greatly to the protection of children in such positions, and simultaneously represent a guideline for States Parties with regard to determining and granting refugee status to children. Moreover, it would ensure legal certainty in matters related to child refugees and asylum-seeking children, 
and thus protect the best interest of the child. The CRC has seen several revisions, but its provisions still do not provide a definition of child refugee.

There has yet to be created an international law instrument that will provide complete guidelines or obligations of States Parties in regard to granting refugee status to children or treatment of child refugees and asylum-seeking children. Per Hathaway and Foster (2014), the definition of refugee requires well-founded fear on two grounds: persecution and lack of protection. When persecution and lack of protection occur in relation to children or unaccompanied minors, a swift, effective and uniform protection procedure is in the best interest of the child. Despite being applicable to children, the CSR bears no express mention of child refugee. Comparably, while the CRC recognizes child refugee as a term, and offers - though limited - guidelines to States Parties in regard to granting and assessment of refugee status of children, neither it provides the definition of child refugee. Strictly speaking, as established by Goodwin-Gill (1995), neither the CSR nor the CRC extend a satisfactory level of protection to child refugees and asylum-seeking children.

The 2009 UNHCR's Guidelines covered a number of important child refugeerelated issues, such as well-founded fear of persecution, application of exclusion clauses to children, and other CSR provisions (United Nations High Commissioner for Refugees (UNHCR), Guidelines on International Protection No. 8, 2009). The 2009 Guidelines are significant, inter alia, for establishing that child refugee rights are not limited to the rights guaranteed under the CSR, but rather include all human rights that belong to all people (UNHCR, Guidelines on International Protection No. 8, 2009).

Additionally, where a child does not meet the conditions set out in Article 1 (a) (2) to the CSR, the 2009 UNHCR's Guidelines provide for the child's legal protection in accordance with its special needs as a child (UNHCR, Guidelines on International Protection No. 8, 2009). It derives from the above provisions that a greater coherence and interpellation between international refugee law and international law relating to children is needed. Accordingly, the findings of the 2009 Guidelines indicate that the CRC is a major factor in the protection of child refugee rights and their best interest. Per_Pobjoy, there are at least three ways in which the CRC can be relevant in considering child refugee status. Firstly, the CRC could offer better procedural safeguards than those provided for under international refugee law. Secondly, the CRC could be envisaged as an interpretative act in interpreting the CSR. And thirdly, outside the system of international refugee protection, the $\mathrm{CRC}$ could represent an independent source in regard to the status of child refugees.

The above analysis indicates that the interpellation of the CSR and the CRC is a key component in the protection of child refugees, unaccompanied minors, 
and asylum seekers. That the CSR is the umbrella international document in regard to refugee protection is clear, precisely as it bears no mention of the rights and needs of child refugees or of the obligations of the state. In accordance with their particularly vulnerable position, both the provisions of the CRC and the UNHCR's Guidelines must be taken into account to ensure complete protection of child refugees, unaccompanied minors and asylumseeking children.

\section{PROTECTION OF CHILD REFUGEES AND UNACCOMPANIED MINORS IN EU LAW - DE LEGE LATA}

In terms of the rights of the child, EU legislation is built on international law, primarily the CRC. Per Stalford (2012), the term child in EU legislation varies, often depending on the context, which may be biology- or age-related, and occasionally relate to the dependence on parents and legal representatives.

In its Article 3 (3) and (5), the Treaty on European Union (TEU) underscores child rights protection as an important goal of the EU. Article 24 to the Charter of Fundamental Rights of the European Union (CFR) prescribes that children are to have the right to such protection and care as is necessary for their wellbeing, that they may express their views freely, which views shall be taken into consideration on matters which concern them in accordance with their age and maturity; that in all actions relating to children, whether taken by public authorities or private institutions, the child's best interests is to be a primary consideration; and that every child is to have the right to maintain on a regular basis a personal relationship and direct contact with both his or her parents, unless that is contrary to his or her interests. The primary EU legislation patently relies on the provisions of the CRC, thereby promoting children's rights protection in compliance with international law. While Article 24 does not define the term child or its age, it should be deemed that - given the regulation of most MSs (MSs) - child entails persons under the age of 18 (Lamont, 2014). Article 24 to the CFR emphasizes that the EU and its MSs must take into account principally the best interest of the child in all actions concerning children, including EU action within the framework of competence for asylum and immigration policy (Lock, 2020, p. 2175).

In general terms, the rights of child refugees and unaccompanied minors are regulated subsidiarily by the asylum and migration legal framework that collapsed at the height of the 2015-2016 refugee crisis, revealing major shortcomings (Metcalfe-Hough, 2015). Notable areas of concern include the rule of first entry under which the MS in which an asylum seeker first registered is responsible for the entire procedure (Goldner Lang 2017), which rule the CJEU confirmed in its case law (A.S. v Slovenia, 2017; Jafari, 2017), and 
certain MSs' non-compliance with the principle of solidarity in the nonenforcement of the decision on the two-year resettlement program for 22,000 refugees (Šelo Šabić, 2017, pp. 5-6). As early as 2016, the EC presented proposals for the reform of the Common European Asylum System, which included the reform of the Dublin Regulation with a view to a better distribution of asylum applications between EU MSs (European Commission - Press release, 2016). However, MSs failed to reach an agreement on the division of responsibilities.

In addition to primary and secondary legislation, soft law instruments are of great importance for children's rights in the EU. The EC's Strategy on the Rights of the Child (2006) emphasizes that the goal of the EU is to have the rights of children as immigrants, asylum seekers and refugees fully respected in the EU and in MSs' legislation and policies. From a legal and political perspective, Kišūnaite (2019) finds, the EU possesses the necessary prerequisites to develop a contextual environment adapted to children's rights, but this has yet to happen in the EU. Further per Kišūnaite, policies and soft law in the EU continue to reflect a fragmented approach to the protection of children's rights, which issue could be solved by creating a single comprehensive document for the protection of children's rights.

The EU Agenda on the Rights of the Child was a recurrent warning and a call to MSs and institutions for better protection of children and their rights. The Agenda calls for the application of the CRC and the protection of both children within the justice system and at-risk children, highlighting, inter alia, the issues faced by asylum seekers' children and unaccompanied child refugees. It also highlights the need to change asylum law in relation to child migrants as well as asylum-seeking children and unaccompanied minors (European Commission, EU Agenda for the Rights of the Child, 2011, p. 9).

The EU Guidelines on the Promotion and Protection of the Rights of the Child (2017) underscore that child migrants and refugees, as well as unaccompanied minors, are at increased risk, remind of international standards in the field of children's rights protection, and lay down comprehensive instructions and concrete measures to promote them. In its Communication on the protection of children in migration (2017), the EC stated that child protection is an expression of the implementation of EU law and of compliance with the CFR and international humanitarian law on the rights of the child. The Communication sets out the measures that the EC and MSs must implement with the help of the European Border and Coast Guard Agency, the European Asylum Support Office (EASO) and the EU Agency for Fundamental Rights. The Communication attaches priority to strengthening of child protection systems on migration routes, supports partner countries in child protection system development and cross-border cooperation in the field of child protection, as 
well as projects aimed at protecting unaccompanied children in third countries, and actively implements EU Guidelines on the Promotion and Protection of the Rights of the Child.

In March 2021, the EC adopted the EU Strategy on the Rights of the Child, as well as the Proposal for a Council Recommendation Establishing a European Child Guarantee. While aimed at promoting equal opportunities for children at risk of poverty or social exclusion, the Strategy and the Recommendation also address migration-related issues (EU Strategy on the Rights of the Child, 2021).

In common to the above-mentioned EU documents is the desire to protect the rights of the child and his or her best interest. But can the EU irrespective thereof effectively improve, formulate, support and enforce the rights of the child (Staford, 2019)? A near-decade ago, McGlynn (2002) pointed out the impact of the CFR on the development of children's rights, criticizing its haphazardness in seemingly being a compromise between different conceptions of children's rights deriving from different international documents. The rights of child refugees and unaccompanied minors have recently become a particular issue in the $\mathrm{EU}$, brought to the forefront by the refugee and migration crisis that began in 2015. In the review process, the Dublin system addressed the issue of applying this system to child refugees and unaccompanied minors differently, in which the CJEU played a major role (MA and Others v Secretary of State for the Home Department, 2013).

The Dublin system, as based on the Dublin III Regulation and the EURODAC Regulation, sets out a clear rule of first entry: a third-country national found in a MS must return to either the country of first entry or the country of first illegal entry. Over time, the Dublin system employed different approaches to returning children and unaccompanied minors to the country of first entry. Namely, the Dublin II Regulation did not contain any provisions on the best interests of the child, instead prescribing that the MS in which the application was made was responsible for the application of a child or unaccompanied minor.

The introduction of protective measures for children and unaccompanied minors in the Dublin III Regulation translated to a full implementation of the child's best interests principle in the Dublin system, ultimately representing a major shift regarding the rights of the child compared to the Dublin II Regulation (Hruscha and Maiani, 2016, p. 1507). Nevertheless, certain concerns persisted in regard to the rights of children and unaccompanied minors, i.e., the possibility of their application having been made in a country where they are no longer located, or their application having been made in multiple MSs. Such concerns have been addressed by the CJEU in its judgment in MA and Others v. Secretary of State (2013). Therein, the CJEU took the position that it was in the interest of the unaccompanied child or minor not to 
prolong the procedure for determining the responsible MS. In its view, unaccompanied children or minors ought to have quick access to the refugee status determination process. It follows from the judgment that the MS responsible for processing the asylum application should be that MS in which the unaccompanied child or minor is located. The CJEU also ruled on the interpretation of the term minor and established that a minor within the meaning of the Directive on the Right to Family Reunification is any third-country national or a stateless person who was under the age of 18 when entering the territory of a MS, i.e., at the time of applying for asylum in that country, but who, during the asylum procedure, attained the age of majority, after which he or she was granted refugee status (Court of Justice of the EU, C-550/16 AS v. Staatssecretaris van Veiligheid en Justitie, 2018, paragraph 65).

In its most recent judgment, the CJEU ruled on the compliance of the national law of an MS - in particular, the Netherlands - with the Return Directive. Namely, Dutch law provides for a different approach to the return procedure depending on the child's age: it ensures conditions for admission in another country for unaccompanied minors under the age of 15 , but not for minors over the age of 15. Most commonly, the Dutch authorities waited for unaccompanied minors to turn 18 to carry out the return procedure. The CJEU, by way of reference to earlier judgments (Boudjlida, 2014, para. 48 and KA et al., 2018, para. 102), determined that such a situation is contrary to the requirement of protection of the best interests of the child at all stages of the procedure, which requirement is laid down in Article 5(a) of Directive 2008/115 and Article 24 (2) of the CFR (Staatssecretaris van Justitie en Veiligheid, 2021, para. 54). In addition, the CJEU ordered that MSs consider the best interests of the child at all stages of the procedure, which implies a general and comprehensive assessment of the minor's situation (Staatssecretaris van Justitie en Veiligheid, 2021, para. 60).

Such judgments are also supported by the ECtHR's judgments delivered against states precisely on grounds of failing to consider of the best interest of the child. ${ }^{2}$ In broad terms, the two courts established that the best interests of the child are always a priority and as such transcend the Dublin system provisions, invoking the rights guaranteed under the CRC, the CFR and the ECHR. The EC followed with a proposal to amend Article 8 (4) of the Dublin III Regulation, specifically to prescribe that the MS responsible for processing an application is to be the MS in which the unaccompanied child or minor submitted the application (European Commission, Press release, 2014). The Council of the $\mathrm{EU}(\mathrm{CoE})$ took the view that the rule of first entry should inevitably apply to

${ }^{2}$ See more in: Rantsev v. Cyprus, Application no. 25965/04, Tarakhel v. Switzerland, Application no. 29217/12, Rahimi v. Greece, Application no. 8687/08, Elmi and Abubakar v. Malta, Application nos. 25794/13 and 28151/13. 
unaccompanied children and minors. Upon presenting the Proposal for a Regulation of the European Parliament and of the Council establishing the criteria and mechanisms for determining the Member State responsible for examining an application for international protection lodged in one of the Member States by a third-country national or a stateless person (COM/2016/0270 final, recast, 2016) (Dublin IV Proposal), it became clear that the EC endorsed the CoE's opinion for reasons undisclosed, completely ignoring the CJEU ruling in the MA case. In Progin-Theuerkauf's view (2017), the Dublin IV Proposal was incoherent and premature, bringing no significant improvement to the current system, and would only have aggravated the refugee situation had it been adopted. Similarly, the Proposal to amend the EURODAC Regulation did not improve the asylum system whatsoever and was a hurried response to the adoption of the Proposal to amend the Dublin III Regulation, itself another hurried act, as triggered by the refugee and migration crisis (Opinion of the European Parliament Legal Services Advisory Group, 2017). The EU legislator therefore withdrew from the proposal to amend the Dublin III Regulation and the EURODAC Regulation and shifted to new solutions formulated in the New PMA, as adopted in September 2020.

In spite of the CRC's and CJEU's specific definition of minor, the EU legislator still does not apply such provisions where unaccompanied minors and asylumseeking children are concerned, not even in the New PMA.

\section{NEW PACT ON MIGRATION AND ASYLUM: PROTECTION OF CHILD REFUGEES AND UNACCOMPANIED MINORS - DE LEGE FERENDA}

The New PMA, as presented by the EC in September 2020, aims to create a common framework for the sharing of responsibilities and solidarity, while ensuring that no MS bear disproportionate responsibility (Commission Communication on a New Pact on Migration and Asylum, 2020). A key element of this legislative package, which contains as many as nine new proposals, is the broader use of border procedures. In practical terms, the New PMA does not abolish the rule of first entry from the Dublin Regulation but rather confirms it. Such procedures allow for asylum applications submitted by persons without a valid visa to be processed directly at the border or in transit zones, reasoning that detaining asylum seekers at borders or in transit zones would render the return policy more effective (Wessels, 2021). In effect, the New PMA pressures third countries to accelerate returns, proposes a mechanism for monitoring asylum procedures at the EU's external borders, suggests ways in which MSs can act in solidarity, and envisages earmarking of 
$10 \%$ of EU aid budget for migration-related objectives (such as providing resources for third countries that host refugees and other migrants). The cardinal amendments proposed by the New PMA fall into one of three groups: (1) those regulating the external dimension of the EU migration policy, i.e., the EU's relationship with transit and countries of origin (Regulation of the European Parliament and of the Council, COM 610, 2020), (2) those focusing on management of external borders (Regulation of the European Parliament and of the Council, COM 612, 2020), and (3) those proposing a new system for sharing responsibilities between EU MSs (Rasche and Walter-Franke, 2020).

With Article 50 of the Regulation of the European Parliament and of the Council on asylum and migration management (COM 610, 2020), the EC proposes the restructuring of access to asylum procedures and establishing of a border procedure for applicants considered as having little prospect for international protection. A further novelty is the introduction of a medical examination at entry. Additionally, with this Regulation, the EC seeks to address the lack of division of responsibilities between MSs by introducing a new solidarity mechanism. Should an MS be found to suffer under migratory pressure, the EC may identify measures appropriate to address the situation, which may include assistance from other MSs. For such cases, Article 55 of the said Regulation provides for MSs to submit a solidarity response plan, offering one of the three types of contribution: relocating asylum seekers (who are exempt from the border procedure), providing operational support, or extending the so-called return sponsorship.

With the New PMA, the border procedure is no longer an exception, but a fundamental procedure in approaching asylum seekers. Article 41 of the Proposal for a Regulation establishing a common procedure for international protection in the Union and repealing Directive 2013/32/EU (COM 611, 2020) requires that $\mathrm{MSs}$ ' border procedures last a maximum of 12 weeks from the first registration.

In addition, Article 41 introduces automatic returns into the border procedure. More specifically, the return border procedure applies to applicants, thirdcountry nationals or stateless persons whose applications have been rejected within the asylum border procedure. The EU's goal with the New PMA is to resolve asylum applications within the border procedure (and - if the application is rejected - to automatically activate the return procedure) with a view to keeping as many applicants, third-country nationals or stateless persons in border zones as possible. However, under the legislative proposals produced by the New PMA, MSs may elect to initiate the standard asylum decision procedure, albeit exclusive of the option of automatic returns. Indeed, and contradictorily, while Article 43 of the said Proposal provides for the border procedure to take place at the border or in transit, Article 41 provides for the 
asylum border procedure to be carried out only if the applicant had not thus far been allowed to enter MSs' territory. In practice, this translates to MSs being more likely to carry out border procedures.

In theory, the amendments adopted by the New PMA represent clearer criteria for determining to whom the border procedure applies. However, if the proposed amendments were to be adopted, they may be expected to result in legal uncertainty for asylum seekers, in turn reducing the quality of asylum proceedings (Rasche and Walter-Franke, 2020, p. 3). If refugees can be denied as much as temporary protection, human rights protection or safe return, refugee law at the international and European level remains incomplete (Goodwin-Gill and McAdam, 2007).

The measures proposed by the EC in its Proposal for a Regulation establishing a common framework for EU asylum and migration management strengthen the right to family reunification, taking into account the current realities of many families, in particular by extending the Regulation to siblings and families in transit (Proposal for a Regulation of the European Parliament and of the Council on asylum and migration management, Article 2 (g) (v)). The proposed amendments also aim to strengthen the principle of the best interest of the child by establishing mechanisms to determine the best interest of the child in all circumstances, including the transfer of minors without adverse effects on the child. Under the amendments, unaccompanied minors would be given priority for relocation. In its recommendation for solidarity measures, the EC gives priority to the relocation of minors, providing for a financial incentive (EUR 12,000 flat-rate) for MSs taking responsibility for the treatment of unaccompanied minors (Proposal for a Regulation on asylum and migration management, Art. 72).

Relocation decisions are the key decisions for the life and safety of the child, the assessment preceding which should thus be conducted formally and with due care, as well as supported by effective and timely cross-border cooperation and additional procedural safeguards. Many an organization agrees that unaccompanied children and minors should also be excluded from return process sponsoring, seeing as how migration control cannot outweigh the institution of the best interest of the child (Joint statement on the impact of the Pact on Migration and Asylum on children in migration, 2020).

The New PMA provides for procedures that are to take place at the EU's external borders. Under the provisions of the New PMA, unaccompanied children, as well as children under the age of twelve together with their families, are to be exempted from border procedures, save in exceptional circumstances such as on grounds of national security (Proposal for a Regulation establishing a common procedure for international protection, Art. 41 (5)). Such setting of 
the age limit of a child outright contradicts the definition of child under the CRC and the case law of the CJEU, which determine it as any person under the age of eighteen. A burning issue is the current practice of treating asylumseeking children and minors as asylum seekers primarily and not children. While they may be asylum seekers, they are children and minors first, and as such must be protected primarily by international law relating to their protection. As it is, the new PMA should be brought in full accordance with international law protecting the rights of the child as well as international refugee law, and accordingly strengthen the application of the principle of the best interest of the child.

Additionally, were the New PMA to be adopted, the retention of asylum seekers would no longer be ultima ratio but instead prima ratio as part of the border procedure, which would apply directly to both unaccompanied children and minors. In their joint comment on the New PMA proposal, Greece, Spain, Malta and Italy warned that, while the EC's proposal does not explicitly include this possibility, the final regulation of border procedures must be made sure to not pave the way to undesirable effects. The four states condemned the establishment of large closed centers at the external borders, noting that the proposed asylum and migration management must fully respect human rights and the rights of asylum seekers (New Pact on Migration and Asylum: comments by Greece, Italy, Malta and Spain, 2020 ). Overall, while the entirety of the Proposal as is centers on illegal entry and the prevention thereof, illegal entry must not be grounds for detaining asylum seekers. Many an organization expressed concern over the likelihood of pre-entry checks and border procedures to effect longer detention times for children. While some children would be exempted from the border procedure, all children would be subject to the pre-entry procedure. In practical terms, all children arriving in the EU irregularly could be detained for up to ten days. At worst, as provided for under Article 41 (a) (2) of the Proposal for a Regulation establishing a common procedure for international protection, children as well as adult asylum seekers could be detained under border procedures for up to 12 weeks. The maximum detention period would be determined in accordance with the Return Directive, under which detention could be extended to 6 months in certain conditions, and exceptionally a maximum of further 12 months (Return Directive, Art. 15 (5) and (6)). This would mark the first time that the EU would pass legislation in which immigration of children could become the rule, not a last resort (Joint statement on the impact of the Pact on Migration and Asylum on children in migration, 2020). There is no legitimate reason for the New PMA to contain provisions that protect only children under the age of 12 from detention. Since the New PMA does not bear express mention of the detention of asylum seekers, its provisions and rules on detention are vague, thus prescribing it tacitly. This fact is especially contentious in light of Article 41 (5) of the 
Proposal for a Regulation establishing a common procedure for international protection: in being applicable only to children under 12 and unaccompanied minors means, it omits special provisions for minors aged 12 to 18 , even in regard to detention. It follows that the aim of asylum policy with this Proposal - instead of creating a common way of creating uniform rules and harmonizing procedures - has become the fight against illegal entry into the EU. Such a goal cannot lead to a sound and uniform asylum policy.

Such solutions are sure to diminish the human rights of asylum seekers. By contrast, in 2013 the EC took the view that border procedures should employed in exceptional circumstances only as they imply detaining of asylum seekers and unaccompanied minors (Communication from the Commission to the European Parliament, 2013, p. 4). This strongly suggests that the detention of asylum seekers at the EU's external borders would in fact constitute deprivation of liberty and not a mere restriction on freedom of movement. Detention would no longer be the exception but the rule. The New PMA must therefore be amended so as to effect development and strengthhening of the Common European Asylum Policy that would in turn protect the human rights of asylum seekers, especially unaccompanied children and minors.

While the UNHCR Guidelines generally preclude the detaining of children, the EU legislation does not prohibit the detention of any at-risk group, including minors and unaccompanied minors (UNHCR, Guidelines, 2012, p. 34). The vulnerability of children must be observed and understood as a correlation between their personal status, environment, and the danger that is particular to each child. In other words, a child's vulnerability is not a general preclusion, but a personal one that is particular to each child depending on his or her environment, personal status, and threatened danger (Vandenhole and Ryngaert, 2012, p. 72). Per Article 37 of the CRC, children must not be unlawfully and arbitrarily deprived of their liberty. Should it be requisite, the arrest, detention or imprisonment of a child is to be carried out in conformity with the law as a last resort for the shortest possible period of time. As Hailbronner and Thym (2016) underscore, entry and border control rules must always be aligned primarily with refugee rights and human rights, and as such be a priority action.

Instead of contributing to the protection of children and minors, and contrary to the decision of the CJEU in the MA case, the New PMA - similarly to the abandoned Dublin IV Proposal - would downgrade their rights as asylum seekers by retaining the rule on relocation of children into the country of first entry. Apart from contradicting the CJEU ruling concering child relocation, this indicates that the new PMA may not be entirely in the best interest of the child and does not protect asylum-seeking children and minors, as required by international and European law. 
A vital aspect that the EC failed to touch upon in the New PMA is the impact of the COVID-19 pandemic on migration and asylum in the EU. Per Le Coz and Newland (2021), the return and reintegration system must be re-examined after the pandemic given that the entirety of the rules on asylum, return and detention procedures under the New PMA look differently under the demands of a pandemic. The legal doctrine since the enactment of the New PMA warns of the inadequacies of such a system. In spite of previous oversights in regard to the criteria for the rule of first entry, the EC opted to retain this rule in the New PMA. The New Pact as a whole cannot be considered pragmatic and realistic as it sidesteps the principal issue of a fair and sustainable shift of responsibilities. Moreover, it creates legitimate doubts about the new mandatory solidarity mechanism (Bakshi, 2020).

Said oversights in the EU asylum system regulation have profound implications for MSs that apply EU legislation, especially for border countries at the EU's external border. A prime example therefor is then the overburdened Greece, where severe violations of the rights of unaccompanied refugee and minor children were found in regard to detention (Doshi and Goyal, 2020), as confirmed by the ECtHR in H.A. v Greece (2019) and Sh.D. v Greece (2019).

The recently adopted EU Strategy on the Rights of the Child is primarily aimed at combating poverty and social exclusion. In identifying children in need and designing their national measures, the Strategy requires that MSs consider the specific needs of children from disadvantaged backgrounds as they relate to homelessness, disability, precarious family circumstances, migration, asylum, minority, race or ethnicity etc. While the goals of the Strategy also indirectly concern refugee children, they do not include goals or solutions specifically addressing the issues they face. With this substantial omission on the EC's part, the new EU Strategy on the Rights of the Child failed to provide guidance for all other EU policies that indirectly regulate the rights of refugee children.

The New PMA must be revised to exempt children under the age of 18 from the border procedure and detainment (especially in prisons and closed detention centers). Determining the MS responsible for processing the asylum application submitted by an unaccompanied child or minor should be made a priority at the border. The MS in which a child is found in should be made responsible for him or her. Such an approach would ensure prompt and efficient action, which is certainly in the best interest of the child. Further, within the revision of the EU legislative framework concerning the rights of the child, provisions of the CRC - the umbrella international document protecting their rights - must be taken into account. Finally, by interpellating the correlation between the CRC and the CSR, the revision must also ensure that all decisions concerning the child be made in his or her best interest. 
Subject to negotiations and approval, the New PMA might be helpful in overcoming the failures of Dublin III. The New PMA might be viewed as a valuable introduction, as it might play an important role in ensuring MSs' uniform asylum policies considering that it does not reiterate the normative inconsistencies of Dublin III.

\section{CONCLUSION}

To determine the level of protection extended to asylum-seeking child refugees and unaccompanied minors, this paper examined the rights of the child under the CRC in general and offered a systematic analysis of international refugee law and international law on children's rights. It was found that the CSR does not address the rights of refugee children in particular, but rather broadly applies to all refugees, including, of course, children. Earlier tendencies aside, the introduction of the definition of child refugee and unaccompanied minors into the CSR has yet to take place. On the other hand, while the CRC mentions the protection of child refugees and unaccompanied minors, it provides limited guidance to States Parties for the refugee status granting procedure. As it is, in terms of the MSs' treatment, neither the CSR nor the CRC provide adequate protection to children and unaccompanied minors as a particularly vulnerable group of asylum seekers. Vital to achieving such protection is the interpellation of the CSR and the CRC, i.e., considering the CRC when applying the CSR with a view to ensuring maximum protection of the child in the asylum procedure. As neither the CRC nor the CSR contain a definition of child refugee and unaccompanied minor, an attempt at one is offered below:

Child refugee or unaccompanied minor in refugee status is any person under the age of 18 who is outside the country of his or her nationality and who - due to a well-founded fear of persecution on grounds of his or her race, religion, nationality, social group or political opinion - may not return to it, owing to its particular vulnerability and status.

A definition mutual to the two conventions governing the issue of refugee status of children and unaccompanied minors is precisely the building block to greater security of every child. In addition, considering that a child refugee or unaccompanied minor is prevented from returning to his or her home country on account of his or her vulnerability and status, the two conventions should lay the foundation for the adoption of special treatment criteria pertaining to such vulnerability and sensitivity, which criteria would be binding upon its States Parties.

The EC's New PMA seeks to overcome political issues and reform the EU's migration policy to achieve better management and efficiency. The New PMA 
proposes nine instruments, of which five are legislative and four are soft law documents, presented in a detailed action plan. The envisaged measures indicate the EC's desire to strike a balance between responsibility and solidarity, and to keep people in their countries. However, should the amendments be adopted, they may be expected to result in legal uncertainty for asylum seekers, in turn producing profound implications for unaccompanied children and minors. In an attempt to reconcile the conflicting interests of different MSs, the New PMA complements and expands previous legislative proposals. However, today, six months after the enactment of the New PMA, the EU has not taken any concrete action to achieve the goals of the PMA or to adopt reformed legislation.

The proposed New PMA does not bring new solutions that would have a practical effect or meaning, especially in regard to the rights of children and unaccompanied minors. To offset this, it would be required that the definition of child refugee and unaccompanied minor be introduced into EU law, that the term child be made coherent with the the CRC and the case law of the CJEU, that persons under 18 be exempt from the border procedure provided for in the New PMA, and that children and unaccompanied minors be exempt from detention.

\section{REFERENCES}

\section{Book}

Freeman, M. (2007). A commentary on the United Nations Convention on the Rights of the Child, Article 3 : the best interests of the child. Leiden: Nijhoff.ž

Goodwin-Gill G. S. and McAdam, J. (2007). The Refugee in International Law. Oxford: Oxford University Press.

Hathaway, C. J. and Foster, M. (2014). The Law of Refugee Status. Chambridge: Cambridge University Press.

Lock, T. (2020). Art 24. In M. Kellerbauer, M. Klamert and J.Tomkin (Eds.), The EU Treaties and the Charter of Fundamental Rights, A Commentary, Oxford, Oxford University Press.

Metcalfe-Hough, V. (2020). The migration crisis? Facts, challenges and possible solutions. London: ODI Briefing. 
Pobjoy, J. (2017). Article 22. In P. Alston and J.Tobin (Eds.), The UN Convention on the Rights of the Child: A Commentary, Cambidge, Cambridge University Press.

Stalford, H. (2012). Children and European Union - Rights, Welfare and Accounatbility. Oregon: Oxford and Portland.

Van Bueren, G. (2020). The International Law on the Rights of the Child. Leiden, First Published 1998., The Netherlands: Brill Nijhoff Retrieved.

Vandenhole, W. and Ryngaert, J. (2012). Mainstreaming Children's Rights in Migration Litigation: Muskhadzhiyeva and Others v. Belgium. In E. Brems (Ed.), Diversity and European Human Rights: Rewriting Judgments of the ECHR, Cambridge: Cambridge University Press.

\section{Chapter of a Book}

Goldner Lang, I. (2020). Towards "Judicial Passivism" in EU Migration and Asylum Law? In T. Ćapeta, I. Goldner Lang and T. Perišin (Eds.), The Changing European Union: A Critical View on the Role of Law and Courts (pp.76-85). Oxford, Hart Publishing.

Hailbronner, K. and Thym, D. (2016). Legal Framework for EU Asylum Policy. In Kay Hailbronner and Daniel Thym (Eds.), EU Immigration and Asylum Law, A Commentary, 2nd edition (pp. 1023-1054). Oxford, C.H.Beck:Hart:Nomos.

Hrabar, D. (2013). Children's rights in the European Union - legal framework. In A. Korać Graovac and I. Majstorović (Eds.), European Family Law (pp. 53-71). Zagreb, Narodne novine d. d.

Hruscha, B. and Maiani, F. (2016). Regulation (EU) No 604/2013 of the European Parliament and of the Council of 26 June 2013 establishing the criteria and mechanisms for determining the MS responsible for examining an application for international protection lodged in one of the MSs by a third-country national or a stateless person (recast). In Kay Hailbronner and Daniel Thym (Eds.), EU Immigration and Asylum Law, A Commentary, 2nd edition (pp. 1023-1054). Oxford, C.H.Beck:Hart:Nomos.

Kilkelly, U. (2016) The Best Interests of the Child: A Gateway to Children's Rights?. In E. Sutherland and L. Barnes Macfarlane (Eds.), Implementing Article 3 of the United Nations Convention on the Rights of the Child: Best Interests, Welfare and Well-being (pp. 51-66). Cambridge, Cambridge University Press. 


\section{Journal Article with DOI}

Alston, P. (1994). The best interest principle: towards a reconciliation of culture and Human Rights, reconciling culture and Human Rights. International Journal of Law, Policy and the Family, 8 (2), 1-25. doi:10.1093/LAWFAM/8.1.1

Kišūnaite, A. (2019). Children's Rights Protection in the EU: The Need for a Contextual Perspective. Peace Human Rights Governance, 3 (2), 171192. doi: 10.14658/pupj-phrg-2019-2-1

Degol, A. and Dinku, S. (2011). Notes on the principle "Best interest of the Child": Meaning, History and it's place under Ethiopian Law. Mizan Law Review, 5 (2), 319-337. doi: 10.4314/mlr.v5i2.1

Goodwin-Gill, G. S. (1995). Unaccompanied Refugee Minors: The Role and Place of International Law in the Pursuit of Durable Solutions. International Journal of Children's Rights, 3, 405-416. doi: $10.1163 / 157181895 \times 00186$

Progin-Theuerkauf, S. (2017). The «Dublin IV» Proposal: Towards more solidarity and protection of individual rights? Sui generis, 61-67. doi: 10.21257

\section{Journal Article with DOI}

McGlynn, C. (2002). Rights for Children: The Potential Impact of the European Union Charter of Fundamental Rights. European Public Law, 8 (3), 387-400.

\section{Blog post}

Bakshi, G. (2020, November 23). Adieu Dublin! But what's next? European Law Blog, News and Comments on EU Law. Retrieved from https://europeanlawblog.eu/2020/11/23/adieu-dublin-but-whats-next/

Doshi, H. and Goyal, R. (2020, July 8). The plight of unaccompanied migrant minors in Greek detention system: A national and international perspective, European Law Blog, News and Comments on EU Law. Retrieved from https://europeanlawblog.eu/2020/07/08/the-plight-ofunaccompanied-migrant-minors-in-greek-detention-system-anational-and-international-perspective/

Wessels, J. (2021, January 5). The New Pact on Migration and Asylum: Human Rights challenges to border procedures. Refugee Law Initiative. Retrieved from https://rli.blogs.sas.ac.uk/2021/01/05/the-new-pact-onmigration-and-asylum-human-rights-challenges-to-border-procedures/ 


\section{Policy Papers}

Carrera, S. (2020). Whose Pact? The Cognitive Dimensions of the New EU Pact on Migration and Asylum. CEPS Policy Insigh, 2020 (22), 1-18.

Le Coz, C. and Newland, K. (2021). Rewiring Migrant Returns and Reintegration after the COVID-19 Shock. Migration Policy Institute (MPI), 2, 1-16.

Rasche, L. and Walter-Franke, M. (2020). Clear, fair and fast? Border procedures in the Pact on Asylum and Migration. Policy Paper, Hartie School Jaques Delor Centre.

Šelo Šabić, S. (2017). The Relocation of Refugees in the European Union - Implementation of Solidarity and Fear. Zagreb, Friedrich Ebert Stiftung.

\section{International and European sources of law}

The Convention on the Rights of the Child, adopted at the 44th Session of the United Nations General Assembly on 20 November 1989 (resolution 44/25), entered into force on 2 September 1990. (2021, April, 6). Retrieved from https://www.un.org/en/development/desa/population/migration/genera lassembly/docs/globalcompact/A_RES_44_25.pdf

The Convention relating to the Status of Refugees, adopted on 28 July 1951 by General Assembly Resolution 429 (V) of 14 October 1950, entered into force on 22 April 1954. (2021, April, 6). Retrieved from https://www.ohchr.org/en/professionalinterest/pages/statusofrefugees. aspx

Declaration of the Rights of the Child, A/RES/1386(XIV). (2021, April, 5). Retrieved from https://digitallibrary.un.org/record/195831

Amended proposal for a Regulation of the European Parliament and of the Council on the establishment of 'Eurodac' for the comparison of biometric data for the effective application of Regulation (EU) XXX/XXX [Regulation on Asylum and Migration Management] and of Regulation (EU) XXX/XXX [Resettlement Regulation], for identifying an illegally staying third-country national or stateless person and on requests for the comparison with Eurodac data by MSs' law enforcement authorities and Europol for law enforcement purposes and amending Regulations (EU) 2018/1240 and (EU) 2019/818, 
Impact of the new pact on migration and asylum on child refugees ...

$\operatorname{COM}(2020) 614$ final (2021, April, 6). Retrieved from https://eurlex.europa.eu/legal-content/EN/TXT/?uri=COM:2020:614:FIN

Amended proposal for a Regulation of the European Parliament and of the Council establishing a common procedure for international protection in the Union and repealing Directive 2013/32/EU, COM(2020) 611 final (2021, April, 7). Retrieved from https://eurlex.europa.eu/legalcontent/EN/TXT/?uri=COM:2020:611:F IN

Proposal for a Regulation of the European Parliament and of the Council laying down the criteria and mechanisms for determining the MS responsible for examining an application for international protection lodged in one of the MSs by a third-country national or a stateless person (recast) (2016). COM / 2016/0270 final - 2016/0133 (COD). (2021, April, 13). Retrieved from https://eurlex.europa.eu/legalcontent/EN/TXT/?uri=CELEX\%3A5201 6PC0270

Proposal for a Regulation of the European Parliament and of the Council on crisis and force majeure situations in the field of migration and asylum, $\operatorname{COM}(2020) 613$ final (2021, April, 4). Retrieved from https://eurlex.europa.eu/legal-content/EN/TXT/?uri=COM:2020:613:FIN

Proposal for a Regulation of the European Parliament and of the Council on asylum and migration management and amending Council Directive (EC) 2003/109 and the proposed Regulation (EU) XXX/XXX [Asylum and Migration Fund] COM(2020) 610 final (2021, April, 4). Retrieved from https://eur-lex.europa.eu/legalcontent/EN/TXT/?uri=COM:2020:610:FIN

Proposal for a Regulation of the European Parliament and of the Council introducing a screening of third country nationals at the external borders and amending Regulations (EC) No 767/2008, (EU) 2017/2226, (EU) 2018/1240 and (EU) 2019/817, COM(2020) 612 final (2021, April, 5). Retrieved from https://eur-lex.europa.eu/legalcontent/EN/TXT/?uri=COM:2020:612:FIN

Proposal for a Regulation of the European Parliament and of the Council establishing a common procedure for international protection in the Union and repealing Directive 2013/32/EU, COM/2016/0467 final 2016/0224 (COD) (2021, April, 4). Retrieved from https://eurlex.europa.eu/legalcontent/EN/TXT/?uri=COM\%3A2016\%3A467\%3AFIN 
Regulation of the European Parliament and of the Council introducing a screening of third country nationals at the external borders and amending Regulations (EC) no. 767/2008, (EU) 2017/2226, (EU) 2018/1240 and (EU) 2019/817 (2021, April, 2). Retrieved from https://eur-lex.europa.eu/legalcontent/EN/TXT/?uri=COM:2020:612:FIN

\section{Judgments of the Court of Justice of the EU and the European Court of Human Rights}

Case C-490/16 A. S. vs. Republic of Slovenia (2017). ECR-585. (2021, April, 2). Retrieved from https://curia.europa.eu/juris/document/document.jsf?docid=223857\& doclangEN

Case C-648/11, MA and others vs. Secretary of State for the Home Department (2013). ECLI:367. (2021, April, 2). Retrieved from https://curia.europa.eu/juris/liste.jsf?num=C-648/11

Case C-149/10 ZO and Chatzi vs. Ypourgos Oikonomikon (2010). OJ C 301. (2021, April, 3). Retrieved from https://eur-lex.europa.eu/legalcontent/SK/TXT/?uri=CELEX:62010CA0149

Case C-441/19, TQ vs. Staatssecretaris van Justitie en Veiligheid (2021). ECLI:2021:9. (2021, April, 3). Retrieved from https://curia.europa.eu/juris/liste.jsf?language $=e n \& t d=A L L \& n u m=C-$ $441 / 19$

Case C-249/13, Boudjlida (2014). EU:C:2431. (2021, April, 3). Retrieved from https://curia.europa.eu/juris/liste.jsf?num $=\mathrm{C}-249 / 13$

Case C-82/16, K. A. and others (2018). EU:C:308. (2021, April, 5). Retrieved from https://eurlex.europa.eu/legalcontent/EN/TXT/?uri=CELEX\%3A6201 6CJ0082

Case Rantsev vs. Cyprus, Application no. 25965/04. (2021, April, 5). Retrieved from https://ec.europa.eu/anti-trafficking/legislation-and-case-lawcase-law/rantsev-v-cyprus-and-russia-application-no-2596504_en

Case Tarakhel vs. Switzerland, Application no. 29217/12. (2021, April, 2). Retrieved from https://www.asylumlawdatabase.eu/en/content/ecthrtarakhel-v-switzerland-application-no-2921712

Case Rahimi vs. Greece, Application no. 8687/08. (2021, April, 3). Retrieved from https://www.asylumlawdatabase.eu/en/content/ecthr-rahimi-vgreece-application-no-868708-1 
Case of H.A. and Others vs. Greece, Application no. 19951/16. (2021, April, 5). Retrieved from https://www.asylumlawdatabase.eu/en/content/ecthr-ha-and-others-vgreece-greece-violated-convention-placing-unaccompanied-minors

Case of Elmi and Abubakar vs. Malta, Application no. 25794/13 and 28151/1332. (2021, April, 7). Retrieved from https://hudoc.echr.coe.int/FRE\#\{\%22itemid\%22:[\%22001$168780 \% 22]\}$

Case of Sh.D and Others vs. Greece, F.Y.R.O.M., Austria, Hungary, Slovenia, Croatia and Serbia, Application no. 14165/16. (2021, April, 7). Retrieved from https://www.statewatch.org/media/documents/news/2016/oct/echrsw-intervention.pdf

\section{Internet sources}

European Commission (2021, April, 10). European Union Strategy on the Rights of the Child. Press corner. Retrieved from https://ec.europa.eu/commission/presscorner/detail/en/IP_21_1226

Legislative proposal published COM 0382, and European Commission, Clearer EU rules for unaccompanied minors seeking international protection (2021, April, 10). Press release. Retrieved from https://ec.europa.eu/commission/presscorner/detail/en/IP_14_723

New Pact on Migration and Asylum: comments by Greece, Italy, Malta and Spain (2021, April, 12). Retrieved from http://www.astridonline.it/static/upload/2511/251120-non-paper-pacto-migratorio.pdf

UN Committee on the Rights of the Child (CRC). General comment no. 5 (2003).General measures of implementation of the Convention on the Rights of the Child (2021, April, 12). Retrieved from https://www.refworld.org/docid/4538834f11.html

UN Committee on the Rights of the Child (CRC).General comment No. 20 (2016). on the implementation of the rights of the child during adolescence. (2021, April, 11). Retrieved from https://www.refworld.org/docid/589dad3d4.html

UN High Commissioner for Refugees (UNHCR). Guidelines on International Protection No. 8: Child Asylum Claims under Articles 1(A)2 and 1(F) of the 1951 Convention and/or 1967 Protocol relating to the Status of Refugees. (2021, April, 12). Retrieved from https://www.refworld.org/docid/4b2f4f6d2.html 


\section{Other relevant sources}

Communication from the Commission to the European Parliament pursuant to Article 294(6) of the Treaty on the Functioning of the European Union concerning the position of the Council on the adoption of a proposal for a Directive of the European Parliament and of the Council on common procedures for granting and withdrawing international protection, Brussels (2013). COM 411 final 2009/0165 (COD). (2021, April, 12). Retrieved from https://eurlex.europa.eu/legalcontent/EN/TXT/?uri=CELEX\%3A5201 3PC0411

Determination of Refugee Status No. 8 (XXVIII) (1977). Executive Committee 28th session. Contained in United Nations General Assembly Document No. 12A (A/32/12/Add.1). Conclusion endorsed by the Executive Committee of the High Commissioner's Programme upon the recommendation of the Sub-Committee of the Whole on International Protection of Refugees. (2021, April, 10). Retrieved from https://www.unhcr.org/excom/exconc/3ae68c6e4/determinationrefugee-status.html

European Commission, Press release, Completing the reform of the Common European Asylum System: towards an efficient, fair and humane asylum policy. (2021, April, 12). Retrieved from https://ec.europa.eu/commission/presscorner/detail/en/IP_16_2433

European Commission (2011). Communication from the Commission to the European Parliament, the Council, the European Economic and Social Committee and the Committee of the Regions, An EU Agenda for the Rights of the Child, COM 60 final. (2021, April, 12). Retrieved from https://eur-lex.europa.eu/legalcontent/EN/TXT/?uri=celex\%3A52011DC0060

IRO Constitution (2020). Annexure 2, Part I, [4], Adopted on 15 December 1946 by the United Nations General Assembly. (2021, April, 13). Retrieved from https://treaties.un.org/Pages/ViewDetails.aspx?src=TREATY\&mtdsg _no $=\mathrm{V}-1 \&$ chapter $=5 \&$ clang=_en

European Commission (2020). Communication from the Commission on a new Pact on Migration and Asylum, Brussels, COM 609 final. (2021, April, 9). Retrieved from https://ec.europa.eu/info/sites/default/files/1_en_act_part1_v7_1.pdf 
Joint statement on the impact of the Pact on Migration and Asylum on children in migration (2020). Terre des Hommes Logo, For children, their rights and equitable development. (2021, April, 9). Retrieved from https://www.terredeshommes.org/joint-statement-on-the-impact-ofthe-pact-on-migration-and-asylum-on-children-in-migration/

Communication from the Commission to the European Parliament and the Council on the protection of migrant children (2017). COM 211 final. (2021, April, 12). Retrieved from https://eur-lex.europa.eu/legalcontent/en/TXT/?uri=CELEX\%3A52017DC0211

Opinion of the Advisory Group of the Legal Services of the European Parliament, the Council and the Commission on the Proposal for a Regulation of the European Parliament and of the Council establishing a "Eurodac" fingerprint comparison system for the effective application of Regulation (EU) No 1095/2010 604/2013 laying down the criteria and mechanisms for determining the MS responsible for examining an application for international protection lodged in one of the MSs by a third-country national or a stateless person in order to identify a thirdcountry national or an illegal stateless person and with Eurodac data by law enforcement authorities of the MSs and Europol for law enforcement purposes (recast) (2017). COM (2016) 0272 of 4 May 2016-2011 / 2016/32 (COD) Brussels. (2021, April, 14). Retrieved from

https://eurlex.europa.eu/legalcontent/EN/TXT/HTML/?uri=CELEX:5 2017DC0650\&rid=10

Statute of the Office of the United Nations High Commissioner for Refugees (1959). GA Res 428 (V), Annex, A/1775,1950. (2021, April, 12). Retrieved from https://www.unhcr.org/3b66c39e1.pdf

UN High Commissioner for Refugees (UNHCR) (2012). Guidelines on the Applicable Criteria and Standards relating to the Detention of AsylumSeekers and Alternatives to Detention, replaces 1999 Guidelines on the Applicable Criteria and Standards relating to the Detention of AsylumSeekers. (2021, April, 6). Retrieved from https://www.unhcr.org/publications/legal/505b10ee9/unhcr-detentionguidelines.html

https://www.unhcr.org/publications/legal/505b10ee9/unhcr-detention guidelines.html

UN High Commissioner for Refugees (UNHCR) (2009). Guidelines on International Protection No. 8: Child Asylum Claims under Articles 1(A)2 and 1(F) of the 1951 Convention and/or 1967 Protocol relating to the Status of Refugees, HCR/GIP/09/08. (2021, April, 6). Retrieved from 
https://www.unhcr.org/publications/legal/50ae46309/guidelinesinternational-protection-8-child-asylum-claims-under-articles.html

UNHCR ExCom (2005). Conclusions on the Provision of International Protection Including through Complementary Forms of Protection, No 103 (LVI). (2021, April, 12). Retrieved from https://www.unhcr.org/excom/exconc/43576e292/conclusionprovision-international-protection-including-complementaryforms.html 